40

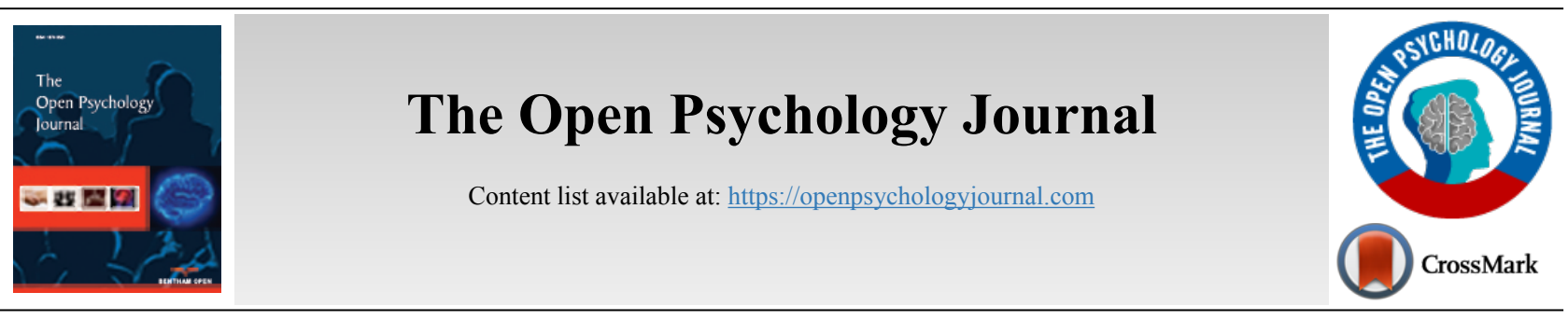

RESEARCH ARTICLE

\title{
Analysis of Russians' Views on Personal Qualities as a Basis for Prosocial Safe Behavior Factors' Identification
}

\author{
Pavel A. Kislyakov ${ }^{1, *}$ and Elena A. Shmeleva ${ }^{1}$ \\ ${ }^{1}$ Department of Psychology, Russian State Social University, 4 Wilhelm Pieck str., Moscow, 129226, Russia
}

\begin{abstract}
:
Background:

Currently, the research on social psychology, security psychology, professional psychology and environmental psychology indicates that prosocial behavior is a predictor or factor for ensuring security (for individuals, groups, societies, and the environment). This indicates the need to justify the category of safe prosocial behavior of individuals.

Aim:

This research focused on the identification of any psychological factor of safe prosocial behavior of an individual based on Russians' views on personal qualities in advancing national interests and socio-cultural transformations.

Methods:

The theoretical and methodological basis of the study was the theory of social norms of pro-social behavior. To examine the Russians' ideas of the safe prosocial behavior, we conducted empirical research, which involved 583 people. In the first stage, we formed a list of possible qualities and motives (descriptors) of the safe prosocial human behavior with the use of focus groups. In the second stage, we used a special questionnaire in order to construct a subjective semantic space of the personal safe prosocial behavior based on the semantic differential method.

Results:

Results of the factor analysis to identify factors affecting safe prosocial behavior in modern society allowed determining seven factors.

\section{Conclusion:}

The obtained data provide an understanding that the safe prosocial human behavior appears to be mainly motivated by institutional and moral norms and is characterized by resources that ensure the psychological stability and well-being of an individual. Norms of collective behavior, religious norms and norms of following national traditions seemed to be dominant in affecting the behavior of individuals.
\end{abstract}

Keywords: Psychological factors, Perceptions, Safe prosocial behavior, Safety, Social norms, Social Psychology.

\begin{tabular}{l|l|l|l} 
Article History & Received: December 04, 2019 & Revised: February 03, 2020 & Accepted: February 19, 2020
\end{tabular}

\section{INTRODUCTION}

Safety issues in modern transitive society remain highly relevant due to some active changes in various spheres of life: geopolitical, ethnic, social and cultural, political, economic, environmental, informational, etc. The new era is characterized by such challenges as interethnic and interfaith conflicts, the refugee crisis, climate change, cyber risks, economic instability, military conflicts and terrorism [1,2]. The Russian society transitivity leads to risks associated with instability of

\footnotetext{
* Address correspondence to this author at the Department of Psychology, Russian State Social University, 4 Wilhelm Pieck str., Moscow, 129226, Russia; Tel: +7-915-848-4010

E-mail: pack.81@mail.ru
}

the Russian society's value system, breach of civil, national and religious identity. People are increasingly put in danger of social risk factors: psychological, informational, social and economic, pseudo-political, pseudo-spiritual, etc. The problem of well-being and safety again gained attention due to the changing forms of social relations that have developed over the decades, ambivalent ideas about passionarity and activities of people in designing the surrounding world, an expressed condition of uncertainty in understanding the goals and trends for society development $[3,4]$.

Deep psychological problems of the Russian society are manifested in progressive alienation, indifference, cynicism, aggression, immoral and antisocial behavior. The society has 
lost many spiritual, moral, and social and cultural norms, including responsibilities towards another person or a group of people who found themselves in a difficult life situation or need help. The problems associated with social and cultural threats and destructive collective behavior lead to the destruction of an individual's identity, loss of his status as a bearer of traditions and a subject of social and economic life $[5,6]$.

Global and local risks of the modern world determine the search for non-material assets (socio-psychological and spiritual resources) that can ensure the safety of a human and society. Such a construct could be the education of an individual, readiness for solidarity, orientation towards positive forms of interaction, towards selfless public service and having prosocial motivation. A demand has been made to develop psychological foundations for the problem of the development of pro-social norms and attitudes in children, youth and the overall population, including altruism, non-violence, humanistic positions, the culture of volunteering, etc.

A transitional process is developing in Russia, leading to the elaboration of a national policy strategy focused on the formation of a safe society and a state based on conservatism and traditionalism, which is based on a careful and positive attitude to the values of people, their foundations and ways of life. Emphasis is placed on the formation of moral consciousness, active citizenship of the individual, and sustainable prosocial attitudes. Social practice in the form of volunteering carried out by people at various social institutions (family, education, profession, public organizations, religion, science, art, etc.) plays a special role therein [7].

\subsection{Literature Review}

Prosocial behavior primarily focuses on the preservation, protection, and development of social communities (of another person, team, public organization, etc.).

The range of definitions for prosocial behavior is quite wide, and includes, in particular:

- Behavior with positive social consequences and contributing to the physical and psychological wellbeing of other people [8].

- Actions that benefit other people, as well as ways to respond to people who show sympathy, cooperation, help, assistance, altruism [9].

- Volitional behavior aimed at the benefit of others, which is of obvious importance for the qualitative interaction between people and groups [10].

- Actions aimed at improving the situation of help recipient, but it is limited to situations in which the subject of the action has no professional duties motivation, and the people themselves (and not the organization) become the object of help [11].

- Positively evaluated interpersonal activities that meet cultural and social standards. The objects of prosocial behavior are not some abstract organizations or people in general, but some specific people who faced various problems (for example, starving, indigent people, victims of natural disasters, etc.) [11].
Social values and standards play an important role in the formation and maintenance of prosocial behavior.

Currently, social psychology, security psychology, professional psychology, and environmental psychology are being researched, indicating that prosocial behavior is a predictor or factor in ensuring security (for individuals, groups, societies, and the environment). The studies by Kline et al. [12], Barile et al. [13], Zabkar and Hosta [14] have addressed the problems of prosocial human behavior to mitigate the environmental impact (a pro-environmental behavior). Taylor et al. [15], identified in their study the specific formation of the prosocial behavior and civic engagement of young people under a protracted political conflict. Moradi et al. [16], revealed a link between the prosocial behavior and the level of corruption in the country. Frazier and Tupper [17], Curcuruto and Griffin [18] studied the impact of prosocial motivation of organizations' employees (managers, subordinates, psychologists) on their psychological and occupational safety. Yang et al. [19], discovered the influence of adolescents' psychological well-being on their prosocial behavior in a virtual environment. The research by Velez et al. [20], revealed the impact of personal perception of a lack of safety on various indicators of prosocial behavior (cooperation, trust, reciprocity, and altruism). Papers by Raposa et al. [21], and Dawans et al. [22], introducethe research on stress effects on the prosocial behavior of individuals. Studies by Rao et al. [23], dealt with the pro-social behavior of people in a disaster zone. Papers by Vives and FeldmanHall [24], Skaar et al. [25] presented the study of the impact of prosocial motives on the risky behaviors of a person.

A review of the previously mentioned research revealed the need to justify the type of individual prosocial safe behavior. We have previously established that the people's focus on consciously maintaining a safe existence of others in the modern community and the whole society, their orientation towards the common good in situations minimizing the social risks (national, cultural, and moral), as well as an individual's willingness to withstand such risk factors are the essential characteristics for the safe prosocial behavior [26].

Social behavior is a projection of sociocultural patterns (i.e. standards and values) and regulations predominant in a certain social environment. Socialization system, set by a society, is a large part of prosocial behavior. Therefore, a chance for an individual to become prosocially active depends on his/her social ideas, attitudes and values.

This research focused on the identification of any psychological factors of safe prosocial behavior of an individual based on Russians' views of personal qualities in advancing national interests and socio-cultural transformations.

The research suggested that they would identify any psychological factors of safe prosocial behavior based both on humanitarian values, attitudes (altruism, social norms, social responsibility, etc.), and sociocultural standards common for the Russian society (culture, traditions, religion).

\section{MATERIALS AND METHODS}

At the first stage, we formed a list of possible qualities and 
motives (descriptors) of the safe prosocial human behavior with the use of focus groups. The study participants were 121 people, 48 men and 73 women (average age 21.5 years). Fourteen standard focus groups were conducted. The authors of the article moderated the focus groups; four post-graduate psychologists of the Russian State Social University assisted them. The groups were homogeneous regarding age and academic status (students). Only volunteers entered the groups. Students from different faculties formed the groups. The following questions were used as an incentive: 1. Mention three personal qualities safe for any society. 2 . What personality traits shall people have to provide a selfless help to others? 3. What personal qualities allow people to help those facing a difficult situation? 4. What personal qualities encourage people to help people with special needs? 5. What personal qualities promote people's participation in environmental actions? 6. Who can be called a patriot? 7. "I feel safe with this person". Give his/her three personal qualities.

The group discussion lasted for 1.5 hours. Questions for the focus group were developed based on a methodological framework that included typology of prosocial behavior (altruistic, compliant, emotional, violent, public, anonymous) [27] and typology of volunteer activity (social, educational, medical, environmental, cultural, corporate, social, sports, civic-patriotic, religious, inclusive) [7].

At the second stage, we used a special questionnaire in order to construct a subjective semantic space of the personal safe prosocial behavior based on the semantic differential method. The respondents rated the safe prosocial behavior descriptors on a 66 bipolar 7-point scale. The initial stimulus used for the semantic differential was "Please, find two lists of qualities (No. I from the left and No. II from the right). Assess the manifestation of the following qualities in a person who you think to be prosocially oriented and socially safe. That is the person who is most focused on the social welfare and security".

Data was collected using the Internet on the service "Google Forms". We comprehended and processed the received answers using qualitative and quantitative methods of analysis, including content analysis, ranking, factor analysis (principal component method, Varimax rotation). Calculations were made based on SPPS 17 statistical software package. Confirmatory factor analysis was performed using structural modeling in Amos v. 20.

To examine the Russians' ideas of the safe prosocial behavior, we conducted empirical research, which involved 583 people ages $18-25$ (23\% - males, $77 \%$ - females; $\mathrm{M}$ age $=$ $22.7 ; 74 \%$ - student, $26 \%$ - worker). Regarding professional affiliation (specialty at the university), $73 \%$ had socioeconomic professions (teacher, doctor, psychologist, speech therapist, social worker, physical education instructor, salesman), $27 \%$ had nonsocioeconomic professions (engineer, programmer, ecologist, economist).

The study was conducted in accordance with the ethical code of The Russian psychological society, and the Protocol was approved by the Academic Council of the faculty of psychology of the Russian State Social University (Protocol No. 4 of 28.11.2018) and with the ethical standards of the World Medical Association Declaration of Helsinki. The participants gave no informed consent to the publication as the data was collected anonymously through the Internet. The questionnaire included the item "I confirm that I have read and understood the purposes, procedure, method and possible inconveniences of participation in the research. I give my consent to participation in the research. I can give up or end the questionnaire at any time".

\section{RESULTS}

All the variables (a pair of descriptors) were roughly normally distributed (i.e., the values of skewness ranged from -2 to +2 , the values of kurtosis ranged from -2 to +2 ). To determine the internal reliability - consistency of the questionnaire items were calculated $\alpha$-Kronbach. The question-naire showed high consistency: $\alpha=0.921 ; \mathrm{M}=3.1 ; \mathrm{SD}=1.82$.

The study made it possible to rank the qualities of a person whom the respondents perceived as prosocially oriented and socially safe, that is, a person most oriented towards the welfare and safety of society. The significance of the safe prosocial behavior descriptors was assessed by calculating the arithmetic mean scores and sum of scores for the answers " +3 ", " +2 " and "+1" and " -3 ", " -2 " and " -1 ", respectively, for each of the questionnaire items (Table 1) followed by definition of the first quartile, the content of which constitutes the core of social ideas about the safe prosocial human behavior descriptors.

Results of the Exploratory Factor Analysis (EFA) that was conducted to identify factors of safe prosocial behavior in modern Russian society allowed determining seven factors that describe $50.8 \%$ of the total variance (Table 2). We applied R. Cattell's scree-test to determine the number of factors and made a scree plot for that purpose. The Point of inflection (K) of the eigenvalues determined the number of factors prior to the straight line after its sharp decline. The scree-test allows identifying the number of factors equal to $\mathrm{K}-1 . \mathrm{K}, \mathrm{K}+1$. We used $\mathrm{K}$ quantity. Results from Confirmatory Factor Analyses (CFA) indicated acceptable-to-good fit of the factors to the data $(\chi 2=6781,002 ; \mathrm{df}=2058 ; \mathrm{p}<0,001$; RMSEA $=0,063$; $\mathrm{GFI}=0,801 ; \mathrm{CFI}=0,847$; Hi $90=0,064)$.

Table 1. Preferences (ranks) in the respondents' choice of the safe prosocial human behavior descriptors.

\begin{tabular}{|c|c|c|c|c|c|c|c|}
\hline Features from List I & $\begin{array}{c}\text { Sum of the Score } \\
\mathbf{( - 3 , - 2 , - 1 )}\end{array}$ & Rank & $\begin{array}{c}\text { Mean Score } \\
(\mathbf{M})\end{array}$ & $\begin{array}{c}\text { Similarly Expressed } \\
\text { Features (0 points), } \mathbf{\%}\end{array}$ & Rank & $\begin{array}{c}\text { Sum of the Score } \\
(\mathbf{1}, \mathbf{2 , 3})\end{array}$ & Features From List II \\
\hline Generous & 1103 & 14 & -1.78 & 13 & 116 & 64 & Vile \\
\hline Caring & 1207 & 7 & -1.99 & 10 & 128 & 44 & Hating \\
\hline Ready & 868 & 34 & -1.30 & 20 & 93 & 110 & Doubting \\
\hline Sacrificing & 816 & 36 & -1.25 & 22 & 101 & 90 & Selfish \\
\hline
\end{tabular}


(Table 1) cont.....

\begin{tabular}{|c|c|c|c|c|c|c|c|}
\hline Passive & 114 & 90 & 1.41 & 16 & 29 & 937 & Active \\
\hline Approved & 807 & 38 & -1.27 & 26 & 114 & 66 & Condemned \\
\hline Collective & 589 & 55 & -0.68 & 34 & 77 & 194 & Individual \\
\hline Useful & 1188 & 8 & -1.93 & 9 & 117 & 64 & Useless \\
\hline Responsible & 1309 & 1 & -2.16 & 8 & 126 & 49 & Irresponsible \\
\hline Conscious & 1262 & 3 & -2.10 & 9 & 130 & 39 & Thoughtless \\
\hline Mindful & 649 & 49 & -0.88 & 35 & 85 & 135 & Intuitive \\
\hline Indifferent & 114 & 91 & 1.68 & 12 & 15 & 1095 & Responsive \\
\hline Values the social & 423 & 59 & -0.34 & 45 & 76 & 222 & Values the Personal \\
\hline Moral & 1213 & 6 & -2.01 & 10 & 129 & 43 & Immoral \\
\hline True & 1235 & 5 & -2.05 & 9 & 132 & 38 & False \\
\hline Evident & 755 & 42 & -1.07 & 26 & 87 & 129 & Hidden \\
\hline Traditional & 338 & 65 & -0.07 & 45 & 70 & 300 & Innovative \\
\hline Politic & 341 & 64 & -0.20 & 47 & 74 & 227 & Independent \\
\hline Sociable & 1064 & 19 & -1.69 & 14 & 104 & 81 & Reserved \\
\hline Neat & 1149 & 10 & -1.88 & 11 & 123 & 51 & Sloppy \\
\hline Joint & 691 & 46 & -1.06 & 35 & 108 & 75 & Separate \\
\hline Sympathetic & 1039 & 21 & -1.67 & 15 & 118 & 64 & Indifferent \\
\hline Attentive & 1132 & 12 & -1.85 & 11 & 121 & 55 & Distracted \\
\hline Cultured & 1266 & 2 & -2.10 & 9 & 131 & 39 & Uncultered \\
\hline Thrifty & 1009 & 23 & -1.60 & 18 & 106 & 78 & Wasteful \\
\hline Selfless & 786 & 41 & -1.02 & 23 & 78 & 189 & Prudent \\
\hline Anxious & 179 & 79 & 1.05 & 22 & 40 & 789 & Calm \\
\hline Aggressive & 81 & 103 & 1.69 & 15 & 18 & 1066 & Peaceful \\
\hline Comforting & 1057 & 20 & -1.69 & 15 & 109 & 72 & Uncomfortable \\
\hline Risky & 452 & 58 & -0.29 & 35 & 71 & 282 & Avoiding Risk \\
\hline Predictive & 656 & 47 & -0.94 & 34 & 95 & 107 & Spontaneous \\
\hline Original & 617 & 53 & -0.84 & 35 & 88 & 126 & Standard \\
\hline Calm & 696 & 45 & -1.01 & 33 & 94 & 108 & Impulsive \\
\hline Credible & 1183 & 9 & -1.94 & 10 & 125 & 50 & Repulsive \\
\hline Group & 554 & 56 & -0.72 & 41 & 83 & 137 & Single \\
\hline Humanistic & 881 & 32 & -1.39 & 24 & 110 & 72 & Misanthrope \\
\hline Independent & 955 & 27 & -1.52 & 18 & 111 & 69 & Dependant \\
\hline Extreme & 308 & 69 & 0.16 & 36 & 61 & 399 & Careful \\
\hline Intolerant & 138 & 82 & 1.39 & 19 & 28 & 948 & Tolerant \\
\hline Viable & 1104 & 13 & -1.78 & 14 & 112 & 68 & Weak \\
\hline Friendly & 1239 & 4 & -2.04 & 11 & 124 & 51 & Aggressive \\
\hline Timorous & 99 & 98 & 1.38 & 21 & 31 & 902 & Bold \\
\hline Indulgent & 622 & 51 & -0.84 & 35 & 86 & 133 & Exacting \\
\hline Believer & 637 & 50 & -0.71 & 36 & 75 & 223 & Atheist \\
\hline Merciful & 1136 & 11 & -1.86 & 13 & 127 & 49 & Cruel \\
\hline Altruistic & 828 & 35 & -1.29 & 25 & 107 & 76 & Selfish \\
\hline National & 496 & 57 & -0.55 & 44 & 80 & 174 & Cosmopolitan \\
\hline Assessing & 335 & 67 & -0.02 & 44 & 68 & 324 & Receiving \\
\hline Admitting & 881 & 33 & -1.41 & 22 & 119 & 59 & Ignoring \\
\hline Competent & 1067 & 17 & -1.74 & 16 & 122 & 55 & Ignorant \\
\hline Weak & 89 & 102 & 1.52 & 20 & 25 & 974 & Strong \\
\hline Initiative & 1002 & 24 & -1.58 & 17 & 105 & 81 & Passive \\
\hline Emotional & 399 & 60 & -0.11 & 38 & 66 & 336 & Discreet \\
\hline Diligent & 349 & 63 & -0.17 & 51 & 73 & 249 & Managing \\
\hline Busy & 369 & 62 & -0.17 & 47 & 72 & 269 & Free \\
\hline Creative & 656 & 48 & -0.95 & 37 & 96 & 104 & Algorithmic \\
\hline Family Man & 721 & 43 & -1.00 & 33 & 84 & 137 & Lonely \\
\hline Young & 621 & 52 & -0.90 & 45 & 99 & 98 & Age-Related \\
\hline Financially Secured & 601 & 54 & -0.84 & 36 & 92 & 112 & In Need \\
\hline
\end{tabular}


(Table 1) cont.....

\begin{tabular}{|c|c|c|c|c|c|c|c|}
\hline Talkative & 705 & 44 & -1.05 & 33 & 100 & 95 \\
\hline Civil & 797 & 39 & -1.17 & 26 & 89 & 115 \\
\hline Adaptive & 1074 & 16 & -1.67 & 14 & 97 & 101 \\
\hline Resilient & 1016 & 22 & -1.63 & 17 & 115 & 65 & Difficult to Adjust \\
\hline Normative & 969 & 26 & -1.55 & 22 & 113 & 68 & Hesitative \\
\hline Infantile & 153 & 81 & 1.13 & 24 & 37 & 811 \\
\hline Environmentally Friendly & 914 & 30 & -1.47 & 24 & 120 & Deviant & 58 \\
\hline
\end{tabular}

Table 2. Results of the factor analysis of the safe prosocial human behavior descriptors.

\begin{tabular}{|c|c|c|}
\hline Factor & Variables Making up a Factor & Variable Weight \\
\hline \multirow{21}{*}{$\begin{array}{l}\text { 1. Institutional Norms. Variance explained } \\
30.9 \%\end{array}$} & Responsible & 0.777 \\
\hline & True & 0.767 \\
\hline & Conscious & 0.748 \\
\hline & Moral & 0.743 \\
\hline & Cultured & 0.737 \\
\hline & Caring & 0.698 \\
\hline & Neat & 0.682 \\
\hline & Useful & 0.651 \\
\hline & Thrifty & 0.632 \\
\hline & Attentive & 0.631 \\
\hline & Credible & 0.619 \\
\hline & Comforting & 0.590 \\
\hline & Friendly & 0.589 \\
\hline & Generous & 0.588 \\
\hline & Sacrificing & 0.526 \\
\hline & Aggressive & -0.501 \\
\hline & Ready & 0.470 \\
\hline & Indifferent & -0.461 \\
\hline & Altruistic & 0.426 \\
\hline & Selfless & 0.416 \\
\hline & Passive & -0.376 \\
\hline \multirow{16}{*}{$\begin{array}{l}\text { 2. Psychological Stability. Variance } \\
\text { Explained } 4.9 \%\end{array}$} & Resilient & 0.638 \\
\hline & Weak & -0.597 \\
\hline & Viable & 0.597 \\
\hline & Initiative & 0.583 \\
\hline & Adaptive & 0.580 \\
\hline & Timorous & -0.563 \\
\hline & Competent & 0.556 \\
\hline & Civil & 0.517 \\
\hline & Normative & 0.500 \\
\hline & Independent & 0.483 \\
\hline & Infantile & -0.477 \\
\hline & Talkative & 0.459 \\
\hline & Environmentally Friendly & 0.451 \\
\hline & Admitting & 0.433 \\
\hline & Financially Secured & 0.425 \\
\hline & Predictive & 0.336 \\
\hline
\end{tabular}




\begin{tabular}{|c|c|c|}
\hline \multirow{10}{*}{ 3. Group Identity. Variance Explained 3.9\% } & Values the Social & 0.711 \\
\hline & Collective & 0.693 \\
\hline & Group & 0.648 \\
\hline & Joint & 0.601 \\
\hline & Evident & 0.522 \\
\hline & Politic & 0.512 \\
\hline & Mindful & 0.420 \\
\hline & Sympathetic & 0.399 \\
\hline & Sociable & 0.372 \\
\hline & Approved & 0.359 \\
\hline \multirow{7}{*}{$\begin{array}{l}\text { 4. National and Religious. Variance } \\
\text { Explained } 3.6 \%\end{array}$} & Traditional & 0.584 \\
\hline & Assessing & 0.508 \\
\hline & National & 0.506 \\
\hline & Young & 0.393 \\
\hline & Intolerant & 0.383 \\
\hline & Believer & 0.354 \\
\hline & Diligent & 0.276 \\
\hline \multirow{4}{*}{ 5. Humanism. Variance Explained 2.7\% } & Indulgent & 0.660 \\
\hline & Calm & 0.453 \\
\hline & Humanistic & 0.430 \\
\hline & Merciful & 0.429 \\
\hline \multirow{4}{*}{$\begin{array}{l}\text { 6. Willingness to Take Risks. Variance } \\
\text { Explained } 2.5 \%\end{array}$} & Extreme & 0.638 \\
\hline & Risky & 0.634 \\
\hline & Original & 0.498 \\
\hline & Creative & 0.449 \\
\hline \multirow{4}{*}{$\begin{array}{l}\text { 7. Emotional Tension. Variance Explained } \\
\qquad 2.3 \%\end{array}$} & emotional & 0.653 \\
\hline & Family Man & 0.472 \\
\hline & Anxious & 0.389 \\
\hline & Busy & 0.322 \\
\hline
\end{tabular}

\section{DISCUSSION}

The factors affecting safe prosocial behavior in modern Russian society.

The variables indicating such safe prosocial behavior descriptors such as responsibility, morality, culture (upbringing), interpersonal trust, generosity, conformance, activity, etc. composed the first factor "Institutional Norms" (Variance explained $30.9 \%$ ). This factor is a leading one as most of its variables are included in the first quartile of social ideas about the safe prosocial human behavior descriptors. Thus, the focus of the safe prosocial behavior is on the well-being of another person and is not due to external social pressure and or the presence of another person, but due to the presence of a number of spiritual qualities (personal dispositions) in the subject. Prosocial behavior is due to socio-cultural norms [28], moral and ethical norms [29], moral identity [30 - 33]. Irwin [34] argues that institutional trust is responsible for prosociality (the belief that institutions encourage others to act in a reliable manner). A study by Sanmartin et al. [35], showed a positive relationship between adolescent's pro-social behavior and social responsibility. The responsibility of an individual to a society is characterized by the conscious adherence to moral principles and norms and is formed in the process of joint activities based on the internalization of social values, norms and rules.

The second factor, "Psychological stability" (Variance explained 4.9\%), includes factors characterizing psychological stability, adaptation potential, initiative, social maturity, ecological culture, etc. This factor is the second most important. The variables included therein constitute predominantly the second quartile of social ideas about the safe prosocial human behavior descriptors. A study by Gritsenko and Kovaleva [36] revealed a positive relationship between different types of prosocial behavior and safety values (values of stability, security and harmony of society, the family and the individual himself). Studies by Yang et al. [19], and Nelson et al. [37], introduced prosocial behavior as a predictor of subjective well-being and personality development (psychological flourishing). Field experiments have shown that people being in an unsafe situation but maintaining psychological stability (exposed to threats of violence [20] or being in a disaster zone [23], demonstrated various forms of prosocial behavior. Studies by Raposa et al. [21], and Dawans et al. [22], showed that prosocial behavior acts as a coping strategy (protective pattern) to reduce a negative impact of stress on mental health.

The third and fourth quartiles of social ideas about the descriptors of safe prosocial human behavior are mainly based on the following factors. The weight of these factors is insignificant, indicating their low priority.

The third factor, "Group Identity" (Variance explained $3.9 \%$ ), has included indicators conditioning the identity of a 
person with the society, social group, and team. It should be noted that the leading indicators of this factor ("collective", "values the social", "group", "joint", and "politic") were estimated on average with the score ranging from 0.2 to 0.72 . At the same time, $34 \%-47 \%$ of the respondents found it difficult to attribute those indicators to one or another pole of the scale (set 0 points). This suggests an ambivalent notation of prosocial behavior according to descriptors in the sample under study. On one hand, the prosocial behavior is understood as collective (oriented to others), and, on the other, as individual (oriented to themselves). This situation is consistent with the fact that helping motives can be both altruistic and selfish. Numerous studies show that prosocial behavior and organizational (collective) behavior (identity) are interdependent [38 40]. The prosocial behavior of team members ensures a favorable psychological environment within the organization, increases organizational loyalty [18], civil behavior (organizational citizenship behavior) [41, 42], corporate social responsibility [43], and contributes to production efficiency increase [44]. However, social isolation reduces the prosocial behavior $[45,46]$.

The fourth factor, "National and Religious" (Variance explained 3.6\%), indicates the religious and national values of a prosocially-oriented person. The leading indicators of this factor ("traditional", "national", and "believer") were on average ranged from 0.07 to 0.71 points. At the same time, $35 \%$ $45 \%$ of the respondents found it difficult to attribute those indicators to one or another pole of the scale (they set 0 points). This suggests an ambivalent notation of prosocial behavior according to descriptors in the sample under study. On one hand, we understood the pro-social behavior as traditional, dictated by religious norms, on the other hand, as liberal and cosmopolitan, and not conditioned by religious norms. There are two opposing points of view in social psychology some authors point to the direct dependence of prosocial behavior on religiosity [47, 48], while others point to its absence or even inverse dependence $[49,50]$. A study conducted by Gritsenko and Kovaleva [36] revealed a positive relationship between different types of prosocial behaviors and values of traditionalism, i.e. the values of respect and maintenance of customs, acceptance and recognition of ideas that exist in the culture. In Russia, they traditionally perceived any manifestations of prosocial behavior in accordance with the worldview that has developed under the influence of both Orthodox norms and age-old traditions. The commandment "Love thy neighbor as thyself" acts as a pro-social regulator of behavior in Christianity, as in all world religions.

The fifth factor, "Humanism" (Variance explained 2.7\%), includes indicators that reflect the humanistic qualities of the individual. A prosocially-oriented individual is able to establish humane relations with other people and does not allow the humiliation of human dignity. Behind the manifestation of a humane attitude are social norms and group expectations.

The sixth factor, "Willingness to Take Risks" (Variance explained $2.5 \%$ ), is associated with the perception of a prosocially oriented individual as a person who risks his/her wellbeing and safety for the benefit of others. The "extreme", "risk" indicators were estimated on average at 0.16 and -0.29 points, respectively. At the same time, about $35 \%$ of the respondents found it difficult to attribute those indicators to a particular pole of the scale (set 0 points). This suggests an ambivalent notation of prosocial behavior according to descriptors in the sample under study. On one hand, the prosocial behavior is understood as a risky one, on the other hand, as cautious. Vives and Feldman Hall [24] showed in their studies that people with a high level of tolerance for uncertainty (risk-taking) demonstrate a higher level of prosociality. A pro-socially oriented individual, risking his/her life and well-being, demonstrates heroism in saving another person.

The seventh factor, "Emotional Concern" (Variance explained $2.3 \%$ ), includes indicators pointing to the predominance of an emotional sphere and an increased level of anxiety. Thus, the study by Zabkar and Hosta [14] showed that the emotional concern ensured the readiness for proenvironmental (prosocial) behavior.

\section{CONCLUSION}

The present findings should be interpreted in light of several important limitations. First, this was a cross-sectional study. Thus, temporal ordering and causality cannot be tested or assumed. Future studies should use longitudinal designs to further examine the patterns that we found. Second, although the sample is large and diverse, it is not necessarily representative of the general population (or even the general population of Russian) in terms of demographics. Replication using different sampling techniques is needed. The reliability of the results can be supported in future studies by using different measures of the same descriptors and factors.

Thus, the obtained data provide an understanding that safe prosocial human behavior appears by Russians mainly to be the behavior motivated by institutional and moral norms and is characterized by resources that ensure the psychological stability and well-being of an individual. Norms of collective behavior, religious norms and norms of following national traditions were on the understanding periphery.

In December 2018, Russia approved the Concept of Volunteerism (volunteering) Development until 2025, which among the priority areas for the development of volunteering, as a form of pro-social behavior, indicated volunteering in the field of civil and patriotic education, volunteering in the cultural sphere, religious volunteering, corporate volunteering. These areas directly relate to the descriptors of the safe prosocial behavior, which are on the periphery of social understanding that highlights the need for program implementation aimed at the formation thereof and implementation of relevant types of social activities. An effective factor in the distribution of the prosocial practices can be the society's demand for volunteering and obtaining a social and typical status thereby, when it will be perceived and assessed in everyday life as a normal and desirable behavior. Effective implementation of the concept of Volunteerism requires the development of all forms of volunteerism. The research updated the necessity of some special forming programs in the field of collective (organizational) behavior (training sessions on team-building, share commitment to prosocial behavior 
ideas, situational simulation, etc.), religious volunteering (educational events, media publications, rebirth of religious mass celebrations, showcasing the positive examples of spiritual support), as well as preservation of cultural heritage and traditions, including any help in maintaining and restoring national cultural values.

\section{AUTHORS' CONTRIBUTIONS}

P.A.K.: collection and evaluation of the questionnaires, analysis of the data, wrote the manuscript, design of the research and statistical analysis of the data; E.A.S.: advice on the theoretical aspects related to prosocial behavior.

\section{ETHICS APPROVAL AND CONSENT TO PARTI- CIPATE}

The study was conducted in accordance with the ethical code of The Russian psychological society, and the Protocol was approved by the Academic Council of the faculty of psychology of the Russian State Social University (Protocol No. 4 of 28.11.2018).

\section{HUMAN AND ANIMAL RIGHTS}

No Animals were used in this research. All human research procedures were followed in accordance with the ethical standards of the committee responsible for human experimentation (institutional and national), and with the Helsinki Declaration of 1975, as revised in 2013.

\section{CONSENT FOR PUBLICATION}

The participants gave no informed consent to the publication as the data was collected anonymously through the Internet.

\section{AVAILABILITY OF DATA AND MATERIALS}

Not applicable.

\section{FUNDING}

The reported study was funded by RFBR according to the research project $\mathrm{N}$ 18-313-20001.

\section{CONFLICTS OF INTEREST}

The authors declare no conflict of interest, financial or otherwise.

\section{ACKNOWLEDGEMENTS}

Declared none.

\section{REFERENCES}

[1] The Global Risks Report 2018. $13^{\text {th }}$ Edition. World Economic Forum, 2018. URL: http://www3.weforum.org/docs/WEF_GRR18_Report.pdf (accessed 20.07.2018).

[2] Ipsos MORI. What worries the world? 9 April 2018. Ipsos, 2018c. URL: https:// www.ipsos.com/ipsos-mori/en-uk/ what-worries-worldmarch-2018 (accessed 20.07.2018)

[3] Rassadina TA. Russians in a "risks society": Emotional and evaluative aspect. Sotsiologicheskie issledovaniya 2013; 9: 95-102.

[4] Yurevich AV. Psychological state of modern Russian society: New trends. Psychology - journal of the Higher School of Economics 2018; 15(4): 695-710.
[5] Shestopal EB, Selezneva AV. Socio-cultural threats and risks in contemporary Russia. Sotsiologicheskie issledovaniya 2018; 10: 90-9.

[6] Yurevich AV. The experience of empirical estimate of psychological state of modern Russian society (statistical data analysis). Psikhologicheskii zhurnal 2019; 40(5): 84-96.

[http://dx.doi.org/10.31857/S020595920006077-0]

[7] Kislyakov PA, Shmeleva EA, Gowin O. Contemporary volunteering in the formation of prosocial behaviour of a person. Obrazovanie i Nauka 2019; 21(6): 122-45.

[http://dx.doi.org/10.17853/1994-5639-2019-6-122-145]

[8] Wispe LG. Positive forms of social behavior: A overview. J Soc Issues 1972; 28: 1-19.

[http://dx.doi.org/10.1111/j.1540-4560.1972.tb00029.x]

[9] Zanden V, James W. Social psychology. $4^{\text {th }}$ ed. N. Y.: McGraw - Hill Inc. 1987.

[10] Eisenberg N, Mussen PH. The roots of prosocial behavior in children. Cambridge studies in social and emotional development. 2003; p. 195.

[11] Kukhtova NV. Content and dynamic characteristics of the personality of adolescent schoolchildren with a prosocial orientation: Monograph. Vitebsk: EE "VSU them. P. M. Masherova 2010; p. 195.

[12] Kline R, Seltzer N, Lukinova E, Bynum A. Differentiated responsibilities and prosocial behaviour in climate change mitigation. Nat Hum Behav 2018; 2(9): 653-61.

[http://dx.doi.org/10.1038/s41562-018-0418-0] [PMID: 31346284]

[13] Barile L, Cullis J. Jones, Will one size fit all? Incentives designed to nurture prosocial behavior. J Behav Exp Econ 2015; 57: 9-16. [http://dx.doi.org/10.1016/j.socec.2015.04.004]

[14] Zabkar V, Hosta M. Willingness to act and environmentally conscious consumer behaviour: Can prosocial status perceptions help overcome the gap? Int J Consum Stud 2013; 37(3): 257-64.

[http://dx.doi.org/10.1111/j.1470-6431.2012.01134.x]

[15] Taylor LK, Merrilees CE, Baird R, Goeke-Morey MC, Shirlow P, Cummings EM. Impact of political conflict on trajectories of adolescent prosocial behavior: Implications for civic engagement. Dev Psychol 2018; 54(9): 1785-94.

[http://dx.doi.org/10.1037/dev0000552] [PMID: 30058816]

[16] Moradi S, Van Quaquebeke N, Hunter JA. Flourishing and prosocial behaviors: A multilevel investigation of national corruption level as a moderator. PLoS One 2018; 13(7)e0200062.

[http://dx.doi.org/10.1371/journal.pone.0200062] [PMID: 30001332]

[17] Frazier ML, Tupper C. Supervisor prosocial motivation, employee thriving, and helping behavior: A trickle-down model of psychological safety. Group Organ Manage 2018; 43(4): 561-93.

[http://dx.doi.org/10.1177/1059601116653911]

[18] Curcuruto M, Griffin MA. Prosocial and proactive "Safety Citizenship Behaviour" (SCB). The mediating role of affective commitment and psychological ownershi. Saf Sci 2018; 104: 29-38. [http://dx.doi.org/10.1016/j.ssci.2017.12.010]

[19] Yang Y, Li PP, Fu XY, Kou Y. Orientations to happiness and subjective well-being in chinese adolescents: The roles of prosocial behavior and internet addictive behavior. J Happiness Stud 2017; 18(6): 1747-62.

[http://dx.doi.org/10.1007/s10902-016-9794-1]

[20] Vélez MA, Trujillo CA, Moros L, Forero C. Prosocial behavior and subjective insecurity in violent contexts: Field experiments. PLoS One 2016; 11(7)e 0158878

[http://dx.doi.org/10.1371/journal.pone.0158878] [PMID: 27472437]

[21] Raposa EB, Laws HB, Ansell EB. Prosocial behavior mitigates the negative effects of stress in everyday life. Clin Psychol Sci 2016; 4(4): 691-8.

[http://dx.doi.org/10.1177/2167702615611073] [PMID: 27500075]

[22] von Dawans B, Fischbacher U, Kirschbaum C, Fehr E, Heinrichs M. The social dimension of stress reactivity: Acute stress increases prosocial behavior in humans. Psychol Sci 2012; 23(6): 651-60. [http://dx.doi.org/10.1177/0956797611431576] [PMID: 22593119]

[23] Rao LL, Han R, Ren XP, et al. Disadvantage and prosocial behavior: The effects of the Wenchuan earthquake. Evol Hum Behav 2008; 32(1): 63-9.

[http://dx.doi.org/10.1016/j.evolhumbehav.2010.07.002]

[24] Vives ML, FeldmanHall O. Tolerance to ambiguous uncertainty predicts prosocial behavior. Nat Commun 2018; 9(1): 2156. [http://dx.doi.org/10.1038/s41467-018-04631-9] [PMID: 29895948]

[25] Skaar NR, Christ TJ, Jacobucci R. Measuring adolescent prosocial and health risk behavior in schools: Initial development of a screening measure. School Ment Health 2014; 6(2): 137-49. [http://dx.doi.org/10.1007/s12310-014-9123-y]

[26] Kislyakov P. Socio-psychological parameters of a person's safe 
prosocial behavior. Proceedings of XVI European Congress of Psychology (ECP 2019). 2019 Jul 2-5; Moscow. 480.

[27] Carlo G, Randall BA. The Development of a measure of prosocial behaviors for late adolescents. J Youth Adolesc 2002; 31(1): 31-44. [http://dx.doi.org/10.1023/A:1014033032440]

[28] Gebauer JE, Sedikides C, Lüdtke O, Neberich W. Agency-communion and interest in prosocial behavior: Social motives for assimilation and contrast explain sociocultural inconsistencies. J Pers 2014; 82(5): 452-66.

[http://dx.doi.org/10.1111/jopy.12076] [PMID: 24127868]

[29] Nejati M, Shafaei A. Leading by example: The influence of ethical supervision on students' prosocial behavior. High Educ 2018; 75(1): 75-89.

[http://dx.doi.org/10.1007/s10734-017-0130-4]

[30] Ding W, Shao Y, Sun B, Xie R, Li W, Wang X. How can prosocial behavior be motivated? the different roles of moral judgment, moral elevation, and moral identity among the young chinese. Front Psychol 2018; 9: 814

[http://dx.doi.org/10.3389/fpsyg.2018.00814] [PMID: 29892249]

[31] Patrick RB, Bodine AJ, Gibbs JC, Basinger KS. What accounts for prosocial behavior? roles of moral identity, moral judgment, and selfefficacy beliefs. J Genet Psychol 2018; 179(5): 231-45.

[http://dx.doi.org/10.1080/00221325.2018.1491472] [PMID: 30280983]

[32] Septianto F, Soegianto B. Being moral and doing good to others Reexamining the role of emotion, judgment, and identity on prosocial behavior. Mark Intell Plann 2017; 35(2): 180-91. [http://dx.doi.org/10.1108/MIP-06-2016-0093]

[33] Hardy SA, Bean DS, Olsen JA. Moral identity and adolescent prosocial and antisocial behaviors: Interactions with moral disengagement and self-regulation. J Youth Adolesc 2015; 44(8): SI, $1542-$.

[34] Irwin K. Prosocial behavior across cultures: the effects of institutional versus generalized trust.Altruism and prosocial behavior in groups. Bingley, England: Emerald Group Publishing Limited 2009; Vol. 26: pp. $165-98$.

[http://dx.doi.org/10.1108/S0882-6145(2009)0000026010]

[35] Gutiérrez SM, Escartí CA, Pascual Baños C. Relationships among empathy, prosocial behavior, aggressiveness, self-efficacy and pupils' personal and social responsibility. Psicothema 2011; 23(1): 13-9. [PMID: 21266136]

[36] Gritsenko VV, Kovaleva YV. Correlation of values of culture with standards and types of prosocial behavior of russians and Byelorussians. Psikhologicheskii Zhurnal 2014; 35(4): 56-67.

[37] Nelson SK, Layous K, Cole SW, Lyubomirsky S. Do unto others or treat yourself? The effects of prosocial and self-focused behavior on psychological flourishing. Emotion 2016; 16(6): 850-61.

[http://dx.doi.org/10.1037/emo0000178] [PMID: 27100366]

[38] Hackel LM, Zaki J, Van Bavel JJ. Social identity shapes social valuation: evidence from prosocial behavior and vicarious reward. Soc Cogn Affect Neurosci 2017; 12(8): 1219-28.

[http://dx.doi.org/10.1093/scan/nsx045] [PMID: 28402506]

[39] Michel JW. Antecedents of organizational citizenship behaviors: Examining the incremental validity of self-interest and prosocial motives. J Leadersh Organ Stud 2017; 24(3): 385-400. [http://dx.doi.org/10.1177/1548051816683895]

[40] Ramarajan L, Berger IE, Greenspan I. Multiple identity configurations: The benefits of focused enhancement for prosocial behavior. Organ Sci 2017; 28(3): 495-513.

[http://dx.doi.org/10.1287/orsc.2017.1129]

[41] Cardador MT, Wrzesniewski A. Better to give and to compete? Prosocial and competitive motives as interactive predictors of citizenship behavior. J Soc Psychol 2015; 155(3): 255-73. [http://dx.doi.org/10.1080/00224545.2014.999019] [PMID: 25559787]

[42] Matherne CF, Ring JK, Farmer S. Organizational moral identity centrality: Relationships with citizenship behaviors and unethical prosocial behaviors. J Bus Psychol 2018; 33(6): 711-26.

[http://dx.doi.org/10.1007/s10869-017-9519-4]

[43] Thornton MA, Rupp DE. The joint effects of justice climate, group moral identity, and corporate social responsibility on the prosocial and deviant behaviors of groups. J Busi Ethics 2016; 137(4): SI, 677-697.

[44] Choi BK, Moon HK. Prosocial motive and helping behavior: examining helping efficacy and instrumentality. J Manag Psychol 2016; 31(2): 359-74.

[http://dx.doi.org/10.1108/JMP-02-2014-0069]

[45] Twenge JM, Baumeister RF, DeWall CN, Ciarocco NJ, Bartels JM. Social exclusion decreases prosocial behavior. J Pers Soc Psychol 2007; 92(1): 56-66.

[http://dx.doi.org/10.1037/0022-3514.92.1.56] [PMID: 17201542]

[46] Sventsitskiy AL, Kazantseva TV. Everyday prosocial behavior of personality as accumulation of social capital. Vestnik SanktPeterburgskogo universiteta. Seriya 12. Psihologiya Sociologiya Pedagogika 2015; 2: 45-55.

[47] McKay R, Herold J, Whitehouse H. Catholic guilt? Recall of confession promotes prosocial behavior. Religion Brain Behav 2013; 3(3): 201-9.

[http://dx.doi.org/10.1080/2153599X.2012.739410]

[48] Einolf CJ. Daily spiritual experiences and prosocial behavior. Soc Indic Res 2013; 110(1): 71-87.

[http://dx.doi.org/10.1007/s11205-011-9917-3]

[49] Saslow LR, Willer R, Feinberg M, et al. My brother's keeper?: Compassion predicts generosity more among less religious individuals. Soc Psychol Personal Sci 2013; 4(1): 31-8. [http://dx.doi.org/10.1177/1948550612444137]

[50] Norenzayan A, Shariff AF. The origin and evolution of religious prosociality. Science 2008; 322(5898): 58-62. [http://dx.doi.org/10.1126/science.1158757] [PMID: 18832637]

This is an open access article distributed under the terms of the Creative Commons Attribution 4.0 International Public License (CC-BY 4.0), a copy of which is available at: https://creativecommons.org/licenses/by/4.0/legalcode. This license permits unrestricted use, distribution, and reproduction in any medium, provided the original author and source are credited. 